\title{
Analysis of The Feasibility of Oyster Mushroom (pleurotus ostreotus) Business in The Village of Gondangmanis, Karangpandan, Karanganyar
}

\author{
Nugraheni Retnaningsih \\ Universitas Veteran Bangun Nusantara \\ Sukoharjo, Indonesia \\ nretna@gmail.com
}

\begin{abstract}
In line with the increasingly popular of oyster mushrooms as a healthy, safe, and nutritious food, and have medicinal properties, moreover supported by the growing development of tourism in Indonesia, the consumer demand for oyster mushrooms in various regions is increasing. The purpose of this research is to determine the value of BEP and analyze the feasibility of oyster mushroom business in the Gondangmanis Village, Karangpandan Sub-District, Karanganyar Regency. The research was carried out with a survey method, with observation, interview techniques, using a questionnaire as a data collection tool. The location in the Gondangmanis village was chosen because in the village there were oyster mushrooms farming. While the sampling of farmers was carried out by census, then analyzed descriptively based on business feasibility analysis, by calculating the amount of BEP (Break Even Point), ROI (Return On Investments), and PP (Payback Period). Data collected is compiled, classified, tabulated, analyzed, and then interpreted. The results of the research showed that the BEP value was achieved in the average production of $257.89 \mathrm{~kg}$ and the average revenue of IDR $1,959,999.63$. Whereas the average production obtained by the respondent farmers is $1,500 \mathrm{~kg}$ and the average revenue is IDR $18,000,000.00$ for each farming (4 months), the cultivation of oyster mushrooms carried out by farmers in Gondangmanis village is already above the BEP, meaning the cultivation of white oyster mushrooms is beneficial. The results of the analysis of the feasibility of the oyster mushroom business obtained the value of average Return On Investment (ROI) of $110 \%$, meaning that the rate of ROI $110 \%$ is much greater compared to the prevailing interest rates in the community, and Payback Period (PP) of 0.906 means the period of time needed to return the capital is 9 months. This means that the cultivation of oyster mushrooms in Gondangmanis village is feasible.
\end{abstract}

\section{Keywords-business feasibility, oyster mushroom}

\section{INTRODUCTION}

Oyster mushrooms that are widely known by farmers in Indonesia in general are white oyster mushrooms (Pleurotus Ostreatus) which have branched stems and are white with large round hoods between 3-15 cm [15]. Oyster mushrooms are edible mushrooms that have high protein compared to other types of fungi. Oyster mushroom protein content is an average of $35.4 \%$ of wet weight, this means the protein content is two times higher than asparagus and cabbage [2]. Oyster mushrooms contain nine essential amino acids that are important for the body, a source of vitamins, especially B1, B2, provitamin D2, and mineral sources, especially potassium and phosphorus [7].

Every individual needs quality food to live a healthy, active and productive life, this can be realized if daily food contains a complete amount of balanced nutrition. Awareness of healthy consumption patterns needs to be instilled early in the family, through the selection of food ingredients and the preparation of a diverse daily menu with balanced nutrition and safe for consumption or abbreviated B2SA (Food Security Office, Ministry of Agriculture, 2017). Food consumption that meets the concept of diverse, nutritious, balanced, and safe (B2SA) can be implemented in families, through the selection of food ingredients and the preparation of daily food menus.

Oyster mushrooms as vegetables that contain complete nutrients can be combined with a variety of delicious dishes, high protein content, does not contain cholesterol, and is safe for consumption because it is free of biological and chemical contamination, so it does not endanger human health [24]. White oyster mushroom can also be used as a meat substitute, according to [14] Oyster mushroom meatballs are one example of alternative food substitute for meat which has high nutritional value, also has elastic properties that resemble chicken meat.

Oyster mushrooms are very good for consumption, especially for those who want to lose weight because they have high fiber content so it is good for digestive health. In addition to fiber, every 100 grams of oyster mushrooms contain protein $(10.5-30.4) \%$, fat $(1.7-2.2) \%$, carbohydrate $56.6 \%$, thiamine $0.2 \mathrm{mg}$, riboflavin $(4.7-4.9) \mathrm{mg}$, niacin $77.2 \mathrm{mg}$, calcium $315 \mathrm{mg}$, and calories 367 [17]. The low fat content makes oyster mushrooms as one of the healthier alternative food ingredients, especially for the elderly and vegetarians who can provide freedom for those who are at risk for cholesterol foods, without having to worry about enjoying meatballs made from oyster mushrooms [14].

White oyster mushroom farming in Gondangmanis village is one of the empowerment of local resources, it is expected to sustain the lives of people in the area, in general the farmers in the village make their own substrate for planting oyster mushroom seeds, because the natural and environmental conditions in Indonesia are very suitable for cultivation of oyster mushrooms, and sawdust raw materials to make the substrate / log for planting oyster mushrooms sufficient and abundant. From an economic perspective, oyster mushroom farming is promising, because at this time when compared to ear mushrooms and other types of vegetables, oyster mushrooms have a more expensive price of IDR $12,000.00 / \mathrm{kg}$ wet while ear mushrooms are only IDR $9,500.00 / \mathrm{kg}$ wet, then it is not uncommon for 
consumers to come from the upper middle class, companies, hotels and restaurants [26]. According to [9] the flesh of oyster mushrooms is quite thick but soft, has white mycelium and can grow quickly.

Whereas in the domestic market the need for mushrooms is quite large along with the increasing popularity of oyster mushrooms as a healthy, delicious, and nutritious food, and has medicinal properties, the consumer demand for oyster mushrooms in various regions is increasing. In its development, oyster mushrooms are now truly populist and much loved by consumers from the lower economic class. Oyster mushrooms are known to the public as a medicine for various diseases, reliable cholesterol-lowering, and good fiber content for digestion [26]. With this background, this research needs to be done to find out whether oyster mushroom cultivation cultivated by farmers in Gondangmanis village, Karangpandan sub-district, Karanganyar district is profitable and feasible to be carried out.

\section{METHOD}

The research stage begins with relevant literature studies and observations to the research location, namely in Karangpandan sub-district, Karanganyar district, because in the area there is an oyster mushroom farm. The research used survey method, with observation, interview techniques and using questionnaires as a data collection tool [25]. Site selection was done intentionally (purposively) namely Gondangmanis village, while the sampling of farmers was carried out by census, namely all farmers in Gondangmanis village who cultivated oyster mushrooms and at the same time made 4 baglogs themselves.

The basic method used is descriptive analytic, which focuses on the actual problems that exist today, first the data is collected, compiled, classified, tabulated, analyzed, explained, then interpreted [23]. The method of analyzing the feasibility of the oyster mushroom business used is BEP, ROI, and PP [11]. To cultivate oyster mushrooms farmers in Gondangmanis village generally do not add outside capital, the method to assess an investment plan that does not consider the time value of money is ROI (Return on Investment) and PP (Payback Period) calculated by the following formula:

$$
\begin{aligned}
& \mathrm{ROI}=\frac{\text { Profit }}{\text { Investment }} \times 100 \% \\
& \mathrm{PP}=\frac{\text { Investment }}{\text { Profit }} \text { / year }
\end{aligned}
$$

The stages of the research carried out are illustrated in the following research flowchart:

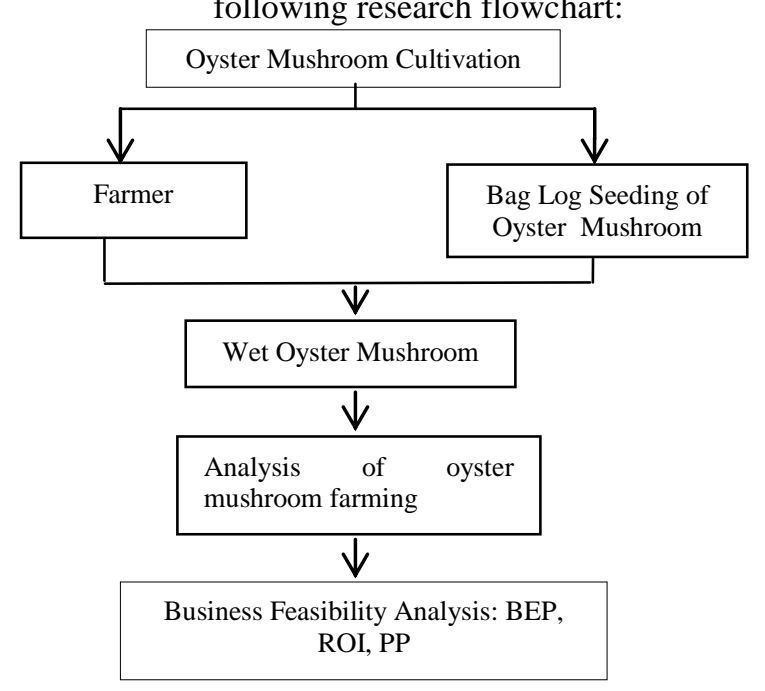

\section{A. Oyster Mushroom Farming}

In general, oyster mushrooms are cultivated by farmers in Gondangmanis as the main livelihood, because oyster mushrooms can produce every day so that they can sustain the economic life of the farming family. According to the editor of [26] the nutritional content of white oyster mushrooms is very complete, nutrition is divided into 3 groups, namely micro elements (protein, fat, carbohydrates, fiber, energy), vitamins (vitamins A, B, C, Niacin, kartene), minerals (calcium, phosphorus, potassium, iron).

Oyster mushroom treatment is very easy and can be done by anyone, both men and women, does not need medicine, just watered with water every morning and evening to maintain moisture. Oyster mushrooms will grow large and fertile in a room with adequate ventilation, not exposed to direct sunlight because the fungus will dry and the seeds cannot grow. Maintenance of oyster mushrooms from seedling planting on bag log media until the last harvest takes between 4-5 months or planting frequency per year can be carried out 2-3 times maintenance. After the mushroom, aged 35-47 days, from harvesting the log substrate can be harvested for the first time, and then harvesting can be done up to 5-6 times per farm. According to [9] home oyster mushrooms are made from bamboo, the roof uses tiles, the walls simply use woven bamboo. The size of the mushroom house has a capacity of 2,000 - 3,000 $\log$ / substrate to plant oyster mushroom seeds with a size (6 x 6) $\mathrm{m} 2$ and can be used for 8-10 times planting.

The cost of fixed capital investment for land rent in rural areas is still relatively cheaper compared to in the city, while for making mushroom houses used bamboo and its roof are used from used tiles which are relatively cheaper. The equipment needed is enough with a sprayer to water the $\log$ bag of oyster mushroom seeds to produce oyster mushrooms. Variable costs in the form of the purchase of log bags for substrate planting oyster mushrooms in the study area are relatively cheaper with the main material of sawn timber that is often found in the surrounding area, 
therefore farmers in Gondangmanis village usually make their own logs. The labor used comes from family workforce, including energy to water the log bag of oyster mushroom seeds and the power to pick up oyster mushrooms that are ready to be harvested.

Usually sold directly to the nearest market in the form of wet or fresh oyster mushrooms, because they cannot stand for long. According to [19] in the dedication to the community the making of oyster mushroom meatballs states that, freshly picked oyster mushrooms should be cooked immediately, or if stored in the refrigerator only last for one day. Oyster mushrooms are only sold in fresh form, fresh oyster mushroom products that can be directly sold are generally of good quality, while the rest of the quality is sold to mushroom processors to be used as processed food.

\section{B. Break Even Point (BEP) Analysis}

BEP is a business condition when the company does not make a profit but also does not suffer losses. Breakevening occurs when the amount of company income is equal to the amount of costs incurred by the company. Based on the results of BEP analysis can be known the minimum number of sales (in the product unit or unit of money) so that the company does not suffer losses [11].This break even point is also the basis for controlling the company's operating activities and as a consideration to determine the selling price.

$$
\begin{aligned}
\mathrm{BEP}_{(\mathrm{X})} & =\frac{\mathrm{TFC}}{\mathrm{p}-\mathrm{VC}} \\
& =\frac{1,960,000}{12,000-4,400} \\
& =\frac{1,960,000}{7,600} \\
& =\frac{257.89 \mathrm{~kg}}{\mathrm{TFC}} \\
\mathrm{BEP}_{(\mathrm{Rp})} & =\frac{1-\underline{\mathrm{VC}}}{\mathrm{p}} \\
& =\frac{1,960,000}{1-\underline{4400}} \\
& =\frac{\mathrm{Rp} .1,959,999.63}{12,000}
\end{aligned}
$$

The results of the BEP calculation obtained $257.89 \mathrm{~kg}$ and IDR $1,959,999.63$. This means that in breakeveness the farmer must sell a minimum of $257.89 \mathrm{~kg}$ of oyster mushrooms or a total revenue of IDR $1,959,999.63$ so that farmers do not suffer losses. Profits will be obtained, if the farmer sells oyster mushrooms above the BEP point. From the calculation of oyster mushroom cultivation conducted by farmers in Gondangmanis village, the average yield was $1,500 \mathrm{~kg}$ with a total revenue of IDR $18,000,000.00$ per farm. Means that the production and revenues achieved by oyster mushroom farmers are already above the breakeven point (BEP). So it can be said that the cultivation of oyster mushrooms by farmers in Gondangmanis village is profitable.

\section{Business Feasibility}

Oyster mushrooms are one of the wood mushrooms that are consumed and cultivated by the community, white oyster mushrooms are easily maintained and high in nutrients and protein, lower fat content compared to vegetables and other types of fungi [21]. According to [13], investment is any capital expenditure or funds invested in various assets, with the expectation that the funds will be received back both short and long term. Investment in current assets is expected to return in a relatively short time or less than 1 year, whereas investment in fixed assets will be received again in a few years and the return gradually through depreciation [20].

According to [21] research analyzes the business feasibility of oyster mushroom cultivation, based on the relevant costs of making investment decisions by calculating: PP. ROI, and NPV.According to [4] to evaluate the feasibility of ordinary businesses, the calculation of benefit cost ratio analysis (B / C ratio) is done by comparing the benefits obtained with the costs incurred. Whereas according to often done, is to calculate the level of return received for the capital invested. Meanwhile, according to [11] to assess the feasibility of a business that does not use outside capital simply by calculating ROI (Return of Investment) and PP (Payback Period). The results of calculations with ROI and PP can be stated as follows:

$$
\begin{aligned}
\text { ROI } & =\frac{\text { Profit }}{\text { Investment }} \times 100 \% \\
& =\frac{9,440,000}{8,560,000} \times 100 \% \\
& =110 \%
\end{aligned}
$$

The Rate of ROI is $110 \%$ much greater than the required loan interest rates and other commercial credit rates that apply in the community, so it can be said that the cultivation of oyster mushrooms is feasible. In other words, the profits earned per farm, namely per planting period for 4 months is $110 \%$ of the invested capital. The greater the ROI level the better, because the faster the return on invested capital and the more efficient use of capital, the smaller the ROI the slower the return on invested capital and the more inefficient use of capital.

$$
\begin{aligned}
\text { PP } & =\frac{\text { Investment }}{\text { Profit }} / \text { year } \\
& =\frac{8,560,000}{9,440,000} / \text { year } \\
& =0.906 \text { or } 9 \text { months }
\end{aligned}
$$


Payback Period (PP) calculates how long the investment can return when the BEP condition occurs. A business is said to be feasible, if the investment return cycle is shorter than the time of the predetermined calculation [10]. Whereas according to [11] PP calculates the period of time the return of funds invested in a particular business, in this case generally every year [5]. Payback Period (PP) >0 means that investment is feasible. The value of $\mathrm{PP}=0.906$ means that the period of time needed to pay back is 9 months or the ability to cover capital takes 9 months. The value of this PP is smaller compared to the average of economic age, so the business is said to be feasible because before the economic life of an investment is up, the capital has returned, the remaining period is an attempt to make a profit.

\section{CONCLUSION}

The results showed that the level of BEP was achieved in the mean production of oyster mushrooms of $257.89 \mathrm{~kg}$ and the average revenue of IDR $1,959,999.63$. When compared with the average production and revenues obtained by the respondent farmers of $1,500 \mathrm{~kg}$ and $\mathrm{Rp}$. . ioyster mushrooms in Gondangmanis village is already located above BEP, meaning that the cultivation of oyster mushrooms is beneficial.

The results of the feasibility study of oyster mushroom business obtained the value of Return On Investment (ROI) of $110 \%$ and Payback Period (PP) of 0.906 or 9 months, meaning that the cultivation of oyster mushrooms was feasible to be carried out in Gondangmanis village, Karangpandan sub district, Karanganyar Regency.

\section{ACKNOWLEDGMENT}

The author would like to thank you to the University Veteran Bangun Nusantara of Sukoharjo.

\section{REFERENCES}

[1] Abdul Halim dan Bambang Supomo. Akuntansi Manajemen. Edisi Pertama. BPFE. Yogyakarta, 2005
[2] Achmad, Mugiono, Tias Arlianti, Chotimatul Azmi. Panduan Lengkap Jamur. Penebar Swadaya. Jakarta, 2013

[3] Bambang, Riyanto. Dasar Dasar Pembelanjaan Perusahaan. BPFE. Yogyakarta, 2004

[4] Cahyono. Beternak Ayam Ras Petelur Dalam Kandang. CV Aneka. Solo, 1994

[5] Danang, Henry. Ekonomi Manajerial dan Bisnis. Esia Media. Bogor, 2009

[6] Dinas Ketahanan Pangan. Beragam, Bergizi, Seimbang, Aman (B2SA). Kementrian Pertanian. Bogor, 2017

[7] Djarijah, N. M. dkk. Budidaya Jamur Tiram. Kanisius. Yogyakarta, 2001

[8] Gittinger. Analisa Ekonomi Proyek-Proyek Pertanian. UI-Press. Jakarta, 1989

[9] Gunawan, A. W. Usaha Pembibitan Jamur. Penebar Swadaya. Jakarta, 2000

[10] Irianto, H., Totok, M. Metode Penelitian dan Evaluasi Agribisnis. Jurusan Agribisnis. UNS. Surakarta, 2010

[11] Halim, Abdul. Manajemen Keuangan Bisnis. Ghalia Indonesia. Bogor, 2011

[12] Hongren et al. Akuntansi Biaya:Penekanan Manajerial. PT. Indeks Kelompok Gramedia. Jakarta, 2005

[13] Kamaruddin, Achmad. Akuntansi Manajemen. Edisi Revisi ke5. Radja Grafindo Persada. Jakarta, 2007

[14] Komariah, dkk. Aneka Olahan Daging Sapi, Sehat, Bergizi, Nikmat. Cetakan Pertama. Agro Media Pustaka. Jakarta, 2005

[15] Parjimo, Agus, A. Budidaya Jamur. Agromedia. Jakarta, 2007

[16] Prawirokusumo, S. Ilmu Usaha Tani. BPFE. Yogyakarta, 1990

[17] Puspitasari. Pleurotus ostreatus Sebagai Nutrisi Pertumbuhan pada Mus musculus. Universitas Al Azhar. Jakarta, 2012

[18] Redaksi Trubus. Jamur Tiram Dua Alam: Dataran Rendah dan Dataran Tinggi. PT Trubus Swadaya. Jakarta, 2010

[19] Retnaningsih, N. IbM Kewirausahaan bagi siswa SMK Negeri Begajah (Membuat Bakso Jamur Tiram. Univet Bantara. Sukoharjo, 2017

[20] Rosyida, Ifa. Pemaksimalan Alat-Alat Analisis Kelayakan Usaha. Jurnal Nasional, 05 Oktober 2007, 2000

[21] Ruliana. Analisis Biaya Relevan dan Pengambilan Keputusan Investasi. Skripsi. LPPM Untag. Samarinda, 2015

[22] Sukartawi. Analisa Usahatani. UI Press. Jakarta, 1995

[23] Surakhmad, W. Pengantar Penelitian Ilmiah. Tarsito. Bandung.E, 1994

[24] Suwito, M. Resep Masakan Jamur Tiram dari Chef Ternama. PT, Agromedia Pustaka. Jakarta, 2006

[25] Singarimbun dan Effendi. Metode Penelitian Survei. LP3ES. Jakarta, 1997

[26] Trubus. Sentra Jamur Kian Menjamur. Trubus. 2010. Jakarta, 2010

[27] Kamaruddin, Ahmad. Akuntansi Manajem. Edisi Revisi ke-5. Raja Grafindo Persada. Jakarta, 2007 